\title{
STATE CONSTITUTIONAL LIMITATIONS ON STATE POWER PROGRAMS
}

The ambitious power program of the federal government has received judicial approval in five recent decisions. ${ }^{x}$ There can be little doubt of the superiority of an integrated federal program over that which could be effected by any single state, and it is encouraging that the recent T.V.A. cases indicate that wide latitude will be given to the national government in its own directly constructed and operated projects. ${ }^{2}$ Nevertheless, Tennessee Electric Pover Co. v. Tennessee Valley Authority ${ }^{3}$ revealed the weakness inherent in any federal undertaking, and thus emphasized the need for state activity. While expressing an eagerness to validate the national power program, the court thought it necessary to base its arguments on the established grounds of interstate navigation and munitions manufacturing. Thus, every proposed federal project faces a possible judicial stalemate in not being able to conform to one of these traditional standards. ${ }^{4}$ A more serious threat to a national program is the possibility of its curtailment by a change in congressional sentiment. 5 Especially is this true in the case of a power program, concerning which there are vital conflicting economic and social outlooks. Despite the present success of the federal power program an analysis of the limits of state activity in this field is not, then, without significance.

The major activity of the states in recent years has been in conjunction with the federal program. Stimulated in many cases by loans and grants from the federal government, authorized by Title II of the National Industrial Recovery Act, ${ }^{6}$ several states have already passed legislation providing for public production and distribution of electric power. ${ }^{7}$ This note will deal primarily with this

I Alabama Power Co. v. Ickes, 58 Sup. Ct. 300 (1938); Duke Power Co. v. Greenwood County, $5^{8}$ Sup. Ct. 306 (r938); Tennessee Electric Power Co. v. Ickes, 5 U.S. Law Week 1038 (U.S. Sup. Ct. April 26, I938); Ashwander v. Tennessee Valley Authority, 297 U.S. 288 (1936); Tennessee Electric Power Co. v. Tennessee Valley Authority, 2I F. Supp. 947 (D.C. Tenn. 1938).

2 Note I supra.

$32 x$ F. Supp. 947 (D.C. Tenn. 1938).

4 Thus it was held in Kansas v. Colorado, 206 U.S. 46 (rgo7), that a dispute between Kansas and Colorado over diversion of water from the Arkansas River was not subject to any Congressional action. The court said that the national government could not control the reclamation of arid lands, since there was no specific grant of any such power in the Constitution.

See, however, Arizona v. California, 283 U.S. 423 (I93I), in which the Court said that a declaration by Congress that the Colorado River was navigable, and therefore subject to federal control, would be accepted without challenge.

$s$ The recent internal difficulties of the T.V.A. have led to an attempt to restrict the entire federal program. See N.Y. Times, p. x, col. 3 (March 26, x938).

648 Stat. 202 (I933), 40 U.S.C.A. $\$ 403$ (1937).

7 Power District Acts: Ala. Code (Cum. Supp. I936) §687 (8); Miss. L. x936, c. 27 ; Nebr. Comp. Stat. (Supp. r937) c. 70, art. 7; Nev. L. 1935, c. 7I; Ore. L. r937, c. 276; S.D. L. 1935, 
type of state public works program. What is said, however, is equally applicable to independent state programs, and is relevant, also, to programs in fields other than public electrification.

In Alabama Power Co. v. Ickes and its companion case Duke Pozver Co. v. Greenwood County 8 the Supreme Court sweepingly upheld the power of the national government to make loans and grants to the states. On the state side of the scheme difficulties, however, are met. Since the states are governments of reserved powers, there would appear to be no reason to question their power to make unlimited public improvements. Incompatible as it may seem, however, with notions of state sovereignty, forty of the forty-eight states have selfimposed constitutional limits on their power to borrow and incur debt.9 Even more striking is the fact that eight of these states, ${ }^{10}$ in addition to one not having a debt limit, ${ }^{\mathrm{II}}$ have absolute prohibitions against state participation in internal improvements.

A satisfactory history of these restrictions is yet to be written. A possible

c. I62; Michie's Tenn. Code (Cum. Supp. I937) §329I (28); Wis. L. I931, c. I98; Wyo. L. $x_{937}$, c. $\times 23$.

Improvement Authorities: Ala. Code (Cum. Supp. 1936) §687 (62); Calif. L. I937 c. 51; S.D. L. I935, C. 73.

Electric Membership Corporations: Ala. Code (Cum. Supp. I936) $\$ 687$ (I8); Ark. L. I937, $\S 2315$; Idaho L. 1937, p. 644; Me. I. I93I, c. 230; Miss. L. I936, c. I84; Nebr. Comp. Stat. (Supp. I937) c. 70, art. 7; N.M. I. I937, c. 100; N.C., Anno. Code I935 § I694 (7); N.D. L. I937, c. Ir5. Penna., Purdon's Penna. Stats. Anno. I938, Title I4, c. 6; S.C. Acts I934, No. 734 ; S.D. L. I935, c. 73; Michie's Tenn. Code (Cum. Supp. 1937) § 3291 (47); Tex. Code I937, art. 528(b); Va. Code I936, $\$ 4057$.

Rural Electrification Authorities: Ala. Code (Cum. Supp. 1936$) \S 687$ (4r); Miss. L. 1936, c. I83; Mont. L. 1935 , c. 35; N.H. L. I935, c. x21, as amended L. I937, c. II8; N.M. L. 1935, c. тor; N.C. Anno. Code $1935 \S$ r694; N.D. L. I937, c. 255; Okla. L. (Supp. r936) § г333 r(a), as amended, L. I937, c. 70, art. 2; S.C. Acts 1935, No. 65; S.D. L. I935, c. 189; Michie's Tenn. Code (Cum. Supp. I937) \&329I (4).

New York has a State Power Authority. Cons. Laws N.Y. I930, p. 2790.

${ }^{8}$ Note I supra.

9 Ala. Const. $\S 2 \mathrm{r} 3$; Ariz. Const. art. $9, \S 5$; Calif. Const. art. I6, $\S \pi$; Colo. Const. art. I, $\S 3$; Fla. Const. art. $9, \S 6$; Ga. Const. art. $7, \S \S 3$, I2; Idaho Const. art. $8, \S \mathrm{I}$; Ill. Const. art. 4, § I8; Ind. Const. art. Io, § 5; Iowa Const. art. 7, § 2; Kans. Const. art. II, $\S 6$; Ky. Const. $\S 49 ;$ La. Const. art. 4, § 2; Me. Const, art. 42; Md. Const. art. 3, § 34 ; Mass. Const. art. 62, § 2; Mich. Const. art. xo, § I0; Minn. Const. art. 9 , $\$ 5 ;$ Mo. Const. art. $4, \S 44 ;$ Mont. Const. art. I3, $\S 2$; Nebr. Const. art. $13, \S 1$; Nev. Const. art. 9, § I $43 ;$ N.J. Const. art. 4, $\S 6$ (4); N.M. Const. art. 9, § 7; N.Y. Const. art. 7, § 2; N.C. Const. art. $5, \S 4$; N.D. Const. art. I2, § r82; Ohio Const. art. 8, § I; Okla. Const. art. ro, $\S 23$; Ore. Const. art. II, $\$ 7$; Pa. Const. art. 9, $\S 4$; R.I. Const. art. 4 , $\S 1$; S.C. Const. art. Io, $\S \S 6,7$, Ir; S.D. Const. art. I3, § 2; Texas Const. art. 3, §49; Utah Const. art. I3, §9; Wash. Const. art. 8, § I; W. Va. Const. art. Io, $\S 4$; Wis. Const. art. $8, \S \S 4,6$, Io; Wyo. Const. art. I6, $\S$ I.

xo Ala. Const. Amend. I; Kan. Const. art. II, § 9; La. Const. art. 4, § I2; Md. Const. art. $3, \S 34$; Mich. Const. art. Io, $\S 14 ;$ Minn. Const. art. 9, $\S 5$; Wis. Const. art. $8, \S$ xo; Wyo. Const. art. $16, \S 6$.

II Va. Const. § I 85 . 
explanation of this amazing phenomenon lies in the fear induced in the constitutional conventions by what seemed at the time to be unfortunate experiences in early state spending. The huge debt created in building New York canals was responsible for the constitutional debt limitations not only in New York but, also, in several other states. ${ }^{12}$ Maryland's experience in railroad building, ${ }^{{ }^{3}}$ and Indiana's Wabash and Erie Canal ${ }^{x_{4}}$ offer an explanation for their limitations. Moreover, many state constitutions were written toward the end of the nineteenth century, and the then prevalent dread of socialism may possibly explain some of these debt provisions. It is not inconceivable that in some states the appearance of the limitations is simply the result of too assiduous a copying of the constitution of a sister state. The presence of restrictions on internal improvements is probably explainable as an additional safeguard against exceeding debt limits. ${ }^{15}$ These emphatically written prohibitions in the constitutions of forty-one states would seem to present an effective bar to state power programs, particularly in face of the notorious difficulties of amending state constitutions. ${ }^{16}$ In the seven states ${ }^{17}$ without constitutional limitations, no difficulty would be expected. Indeed, a recent decision in one of them, New Hampshire, upheld a sweeping plan for state power development. ${ }^{x 8}$

Perhaps it is surprising that state improvement activity has not been confined to these seven states. Yet even in the nine states with absolute prohibition against improvements, the Supreme Court of Kansas, alone, has taken a definite stand that this constitutional provision must be respected. ${ }^{x 9}$ Minnesota has shown some tendency toward restricting state activity, but the presence of conflicting decisions makes future holdings unpredictable. In 1894 the court refused to approve a plan for state grain elevators, ${ }^{20}$ but more recently permitted conservation work ${ }^{21}$ and a college dormitory building. ${ }^{22}$ In I934,

12 Secrist, An Economic Analysis of the Constitutional Restrictions Upon Public Indebtedness in the United States (I9r4). The author suggests that the tendency toward restrictions followed in the wake of the panic of 1837 . See also Newell v. People ex rel. Phelps, 7 N.Y. 9, 84 ( 1852 ); Atty. Gen. v. Pingree, r2o Mich. 55०, 556, 79 N.W. 814, 816 (r899); Young v. City of Ann Arbor, 267 Mich. 24I, 255 N.W. 579 (I934).

${ }_{33}$ Discussed in Bonsal v. Yellott, roo Md. 48I, 60 Atl. 593 (rgo5).

4 Bates, The Borrowing Power under the "Casual Deficit" Proviso of the Indiana Constitution, 8 Ind. L.J. 34 I (I933).

${ }^{25}$ Although Virginia adopted only the improvement prohibition, there is evidence that it too had trouble meeting its debts. See Bates v. State Bridge Comm'n, 109 W. Va. I86, 153 S.E. 305 (1930).

${ }^{36}$ See Stimson, Federal and State Constitutions of the United States $\S 990 \mathrm{ff}$. (I908).

${ }^{27}$ Arkansas, Connecticut, Delaware, Mississippi, New Hampshire, Tennessee, Vermont.

${ }^{28}$ Conway v. New Hampshire Water Resources Board, 5 U.S. Law Week 985 (N.H. Sup. Ct. April 19, 1938), upholding N.H. L. I935, c. I2I, as amended, L. 1937 c. 118.

‘ State ex rel. Boynton v. Atherton, I39 Kan. I97, 30 P. (2d) 29I (r934).

${ }^{20}$ Rippe v. Becker, 56 Minn. Ioo, 57 N.W. 33I (1894).

${ }^{2 x}$ Lipinski v. Gould, I 73 Minn. 559, 218 N.W. I23 (I928).

22 Fanning v. Univ. of Minn., I83 Minn. 222, 236 N.W. 2I7 (I93I). 
however, a dictum contained a clear warning that internal improvements would not be tolerated. ${ }^{23}$ While two of these states have not adjudicated the issue, ${ }^{24}$ the remaining have permitted direct or indirect avoidance of these prohibitions. The courts of Alabama, ${ }^{25}$ Wisconsin, ${ }^{26}$ Wyoming ${ }^{27}$ and Louisiana ${ }^{28}$ have permitted state activity accomplished under the guise of public agencies. The highest court in Maryland went so far as to rule that the prohibition in the state's 1867 constitution could apply only to such improvements as were common at that time and consequently could not bar a state highway program. ${ }^{29}$

The more prevalent debt limits ${ }^{30}$ have been similarly treated judicially. Perhaps the temper of the courts is best illustrated in State ex rel. Hamilton $v$. Martin ${ }^{35}$ where the Supreme Court of Washington found an incipient insurrection in order to justify a bond issue in excess of debt limits. ${ }^{32}$ The state legislatures have confidently gone ahead with power programs necessitating the borrowing of large amounts. ${ }^{33}$ This legislation, drafted largely by the Public Works Administration, makes use of one or more of the four following types of corporations:34 Municipal Power Districts, ${ }^{35}$ Improvement Authorities, State Rural Electrification Authorities and Electric Membership Corporations. The first two take the form of municipal corporations. While they are not, therefore, subject to state limitations, their powers are, in many cases, re-

${ }_{23}$ Moses v. Olson, I92 Minn. r73, 255 N.W. 6r7 (1934).

${ }^{4}$ Michigan and Virginia. The latter, however, has upheld the right of the state, pursuant to its police power, to construct a factory for use by convicts in the making of lime. Shenandoah Lime Co. v. Mann, Governor, Ir5 Va. 865, 80 S.E. 753 (r9r3).

${ }^{25}$ Alabama Power Co. v. Cullman County Electric Membership Corp., 234 Ala. 396, r74 So. 866 (r937) (power development).

${ }^{26}$ Loomis v. Callahan, 196 Wis. 518 , 220 N.W. 816 (1928) (state university dormitories). Cf. State ex rel. Wisconsin Development Authority v. Dammann, 277 N.W. 278 (Wis. 1938).

${ }^{27}$ Arnold v. Bond, 47 Wyo. 236, 34 P. (2d) 28 (1934) (dormitories).

${ }^{28}$ State ex rel. Porterie v. Charity Hospital, I82 La. 268 , x6r So. 606 (I935) (hospital); Board of Comm'rs v. Pure Oil Co., I67 La. 8or, I20 So. 373 (r929) (levee building).

29 Bonsal v. Yellott, roo Md. 48I, 60 Atl. 593 (I905), followed in Welch v. Coglan, I26 Md. I, 94 Atl. 384 (rgr5) and in Ludwig v. County Comm'rs, I3 1 Md. 35 I, ror Atl. 695 (I917), both upholding sewage disposal developments.

${ }^{30}$ Note 9 silpra.

${ }^{3 x}$ I 73 Wash. 249, 23 P. (2d) r (1934).

${ }^{32}$ Compare the equally revealing statement made by the Pennsylvania court in approving a violation of debt limits. "It is never an illegal evasion to accomplish a desired result, lawful in itself, by discovering a legal way to do it." Tranter v. Allegheny County Authority, $316 \mathrm{~Pa} .65$, I73 Atl. 289 (1934).

33 Note 7 supra.

${ }^{34}$ See Geffs and Hepburn, Public Authorities and Co-operatives to Promote the Use of Electricity, 25 Georgetown L.J. 827 (I937) for a complete description of these corporations.

35 Held, constitutional. Clam River Electric Corp. v. Public Service Comm'n of Wis., 274 N.W. I40 (Wis. I937); Tennessee Electric Power Co. v. Fayetteville, 5 U.S. Law Week 984 (Tenn. Sup. Ct., April I9, I938). 
stricted by similar debt provisions ${ }^{36}$ as well as by a host of constitutional and statutory regulations designed primarily for the ordinary municipal corporations. Although these limitations do not always provide an insuperable obstacle to public works programs, their presence makes difficult an extensive development. In addition, an integrated program throughout a state is unlikely because of an almost inevitable lack of centralized authority.

On the other hand, the State Rural Electrification Authorities are state agencies capable of unified state-wide activity. They are formed by the state and managed by a board of directors appointed by the various governors. To effectuate their program they are given the powers common to most corporations as well as the important governmental privilege of accepting Federal aid under Title III of the N.I.R.A. ${ }^{37}$ On dissolution their property remains in the hands of the state. The fourth type of organization, the Electric Membership Corporation, because it is a cooperative which can serve only members within a limited area, does not offer the advantages of a state-wide program. Although operated by a board elected by its members the Corporation's public nature has been acknowledged by at least one court. ${ }^{38}$ Since it, too, can borrow under Title II of the N.I.R.A. and since its property reverts to the state on dissolution, there can be no doubt that in all but form it is a state agency. In spite of any administrative differences, all these organizations are financed by bonds, the principal and interest of which are payable only from the revenues produced by the sale of power. Since the Rural Electrification Authorities offer the chief hope of a really successful state program, this discussion will be limited primarily to them, although much of what will be said does, in fact, apply to the others as well. ${ }^{39}$

It is provided in the bonds of the Electrification Authorities that the states can never be called upon to pay either the interest or principal from general tax revenues. A comparison of the financial structure of these authorities to

${ }^{36}$ See, for example, Ala. Const. $\$ \S 225,226$; Ariz. Const. art. 9, § 8; Conn. Const. Amend. 25; Del. Const. art. $8, \S 8$; Idaho Const. art. $8, \S 3$; III. Const. art. 9 , § I 2 ; Ind. Const. $x_{3}, \S \mathrm{I}$; Iowa Const. art II, $\S 3$; Ky. Const. $\$ \S x_{57}, x_{5} 8 ;$ Me. Const. art. 34 ; Md. Const. art. $3, \S 54$; Miss. Const. art. $4, \S 80$; Mont. Const. art. I3, $\S 6$; Nev. Const. art. $8, \S$ I38; N.M. Const. art. 9, § 9; N.Y. Const. art. $12, \S x$; N.C. Const. art. $5, \S 4 ;$ N.D. Const. art. 6 , § I30; Okla. Const. art. Io, $\S 26$; Ore. Const. art. Ir, $\S 5$; Pa. Const. art. 9, $\S 8$; S.D. Const. Art. I3, $\S 4$; Utah Const. art. I3, $\S \S 3,4$; Vt. Const. $\S 3609$; Va. Const. $\$ \S 115(a)$, I27; Wash. Const. art. $8, \S 6$; W. Va. Const. art. Io, $\S 8$; Wis. Const. art. Ir, $\S 3$; Wyo. Const. art. $x_{3}, \S 3$. There is, also, a large number of statutory restrictions.

${ }^{37}$ Note 6 supra. See also, Geffs and Hepburn, op. cit. supra note 34 .

${ }^{38}$ Alabama Power Co. v. Cullman County Electric Membership Corp., 234 Ala. 396, I74 So. 866 (1937). Cf. State ex rel. Wisconsin Development Authority v. Dammann, 277 N.W. 278 (Wis. 1938).

${ }^{39}$ For discussions of problems peculiar to the municipal corporations, see comment $4 \mathrm{I}$ Yale L.J. II6 (1931); comment 43 Yale L.J. 924 (I934); note 33 Col. L. Rev. 338 (I933); Geffs and Hepburn, op. cit. supra note 34 ; Garwood, Debt Limitations and Tax-free Cities and Towns, 20 A.B.A.J. 705 (1934). 
that of an ordinary private corporation indicates how anomalous is the position of the purchaser of the bonds. If anything, he is a creditor rather than an owner. He has no control; he has a limited return on his investment and the principal is subject to liquidation. Further, the property does not revert to him on liquidation but to the state. The position of the state is very much like that of stockholders who have put up no capital. This is limited liability in its most extreme form. The state has clearly borrowed the money but has pledged its credit only to the extent of the revenue from the property. The question of construction for the courts then is whether this type of debt is within the constitutional prohibition and should the courts decide that technically the bond is not a debt, the further question remains of whether the probability that the state would feel morally bound to pay these obligations in case of default is sufficient to render such a scheme for financing unconstitutional.

Oklahoma, ${ }^{40}$ Texas, ${ }^{41}$ Nebraska, ${ }^{42}$ South Carolina ${ }^{43}$ and Ohio ${ }^{44}$ have, despite debt limits, allowed power projects financed by revenue bonds, on the ground that since the states did not pledge their general credit, the issue did not create a debt within the meaning of the constitutional limitations. While these courts are the only ones thus far to have adjudicated the issue, there is every reason to believe that most of the other courts will follow them.

Of the remaining thirty-five states with debt limits, twenty-four have already approved the use of revenue bonds in other public construction projects on the same theory. ${ }^{45}$ Eight $^{46}$ have never considered the issue and only three ${ }^{47}$

${ }^{40}$ Sheldon v. Grand River Dam Authority, 76 P. (2d) 355 (Okla. 1938).

4x Lower Colorado River Authority v. McCraw, I25 Tex. 268, 83 S.W. (2d) 629 (I935).

${ }_{42}$ State ex rel. Loseke v. Fricke, I26 Neb. 736, 254 N.W. 409 (I934).

${ }_{43}$ Clarke v. South Carolina Public Service Authority, I77 S.C. 427, I8I S.E. 48I (I935).

${ }_{44}$ Kasch v. Miller, I04 $_{4}$ Ohio St. 28x, $x_{35}$ N.E. 813 (x923).

${ }_{45}$ Alabama, Ala. State Bridge Corp. v. Smith, 2I7 Ala. 3 II, 116 So. 695 (I928) (toll bridge); Scott v. Ala. State Bridge Corp., 233 Ala. I2, 169 So. 273 (1936) (toll bridge); Arizona, Bd. of Regents of Univ. of Ariz. v. Sullivan, 45 Ariz. 245, 42 P. (2d) 6rg (I935) (dormitories); California, Calif. Toll Bridge Authority v. Wentworth, 2I2 Cal. 298, 298 Pac. 485 (r93); Calif. Toll Bridge Authority v. Kelly, 2x8 Cal. 7, 21 P. (2d) 425 (I933); Colorado, In re Canal [Footnote 45 continued on facing page]

${ }^{46}$ Iowa, Maine, Maryland, Massachusetts, Nevada, New Jersey, North Carolina, and Utah. In Towa a tendency toward strictness was manifested in State v. Executive Council of State, 207 Towa 923, 223 N.W. 737 (I929) but the precise issue was not discussed. The Supreme Court of Utah has suggested the use of hybrid corporations which would be neither municipal nor state agencies and thus not subject to limitation on either. Lehi City v. Meiling, 87 Utah 237, 48 P. (2d) 530 (I935); State v. Candland, 36 Utah 406, 104 Pac. 285 (19c9).

${ }_{47}$ Idaho, State Water Conservation Bd. v. Enking, 56 Idaho 722, 58 P (2d) 779 (1936) (water conservation); Kansas, State ex rel. Boynton v. Atherton, I39 Kan. I97, 30 P. (2d) 29I (1934) (game conservation); New York, Newell v. People ex. rel. Phelps, 7 N.Y. 9 (1852), affirming Rodman v. Munson, I3 $_{3}$ Barb. (N.Y.) 63 (I852). While these decisions were under the New York constitution of 1846 , there is no substantial change in the present constitution. It will be interesting to note whether the new New York Constitution now being drawn up will make any changes. 
have voiced their dissent. The majority of the cases, where the courts have been called upon to sanction these bonds, have involved the financing of either state university dormitories or toll bridges..$^{8}$ These projects required comparatively small and isolated expenditures. The use of revenue bonds in state power projects could be distinguished on the ground of sheer size. For example, an expenditure of $\$ 40,000,000$ was sufficient to meet the needs of only 137,000 of 6,000,000 potential rural users in the United States. ${ }^{49}$ Moreover, municipal electric plants, established in less than ten per cent of our larger cities, were valued at $\$ 200,000,000$ in $1929 . .^{50}$ Obviously, the lack of a sound financial structure in projects of this magnitude will lead to far wider repercussions than in the case of dormitories. Yet, there is little likelihood of a shift from this line

\section{[Continuation of footnote 45 ]}

Certificates, I9 Colo. 63, 34 Pac. 274 (1893) (irrigation); Florida, Hopkins v. Baldwin, I23 Fla. 649 , I67 So. 677 (1936) (dormitories); Brash v. State Tuberculosis Bd., I24 Fla. I67 167 So. 827 (1936) (sanitarium); Georgia, State v. Regents of Univ. System, 179 Ga. 210, I75 S.E. ${ }_{567}$ (I934) (dormitories). But see, Cartledge v. City Council of Augusta, $88_{3}$ Ga. 4r4, I88 S.E. 675 (1936) (municipal power plant); Illinois, cf. Ward v. City of Chicago, 342 Ill. r67, 173 N. 8ro (r930) (municipal water works); Indiana, of. Underwood v. Fairbanks, 205 Ind. 3 I6, I85 N.E. II8 (1933) (municipal electric plants); Kentucky, Van Hooser v. Univ. of Ky., 262 Ky. 58r, 90 S.W. (2d) ro29 (r936) (university buildings); State Highway Comm'n v. King, $259 \mathrm{Ky} .4 \mathrm{r}_{4}, 82 \mathrm{~S}$.W. (2d) 443 (1935) (toll bridge); Lonisiana, Caldwell Bros. v. Bd. of Supervisors, 176 La. 825, I47 So. 5 ( $19 \mathrm{I}_{3}$ ) (college buildings); Bd. of Comm'rs v. Pure Oil Co., I67 La. 801, 120 So. 373 (1929) (levees); State ex rel. Porterie v. Charity Hospital, r82 La. 268, r6I So. 606 (r935); Michigan, Attorney General v. State Bridge Comm'n, 277 Mich. 373,269 N.W. 388 (1936) (toll bridge); Minnesota, Fanning v. Univ. of Minn., I83 Minn. 222, 236 N.W. 217 (193 I) (dormitories); Missouri, State ex rel. District v. Smith, 337 Mo. 855,87 S.W. (2d) I 47 ( $x_{935}$ ) (sewers); Grossman v. Public Water Supply District, 339 Mo. 344, 96 S.W. (2d) 7or (1936) (water works); Montana, State ex rel. Normile v. Cooney, roo Mont. 39r, 47 P. (2d) 637 (I935) (water conservation); State v. State Bd. of Education, ro2 Mont. r65, 56 P. (2d) ro79 (r936) (college buildings); Nexo Mexico, State v. Regents of Univ., 32 N.M. 428, 258 Pac. 57 I (I927); North Dakola, State v. Davis, 59 N.D. Igr, 229 N.W. I05 (I930) (dormitories) the court reversing the position it took in Wilder v. Murphy, $5^{6}$ N.D. 436,218 N.W. 156 ( 1928 ) (dormitories); Oregon, McClain v. Regents of Univ., I24 Ore. 629, 265 Pac. 4I2 (1928) (dormitories); Pennsylvania, Trante v. Allegheny County Authority, $3^{16} \mathrm{~Pa} .65$, I73 Atl. 289 (r934) (toll bridge); Rhode Island, Opinion to the Governor, I93 Atl. 503 (R.I. 1937) (general improvements); South Dakota, In re Opinion of the Judges, 39 S.D. 8, I62 N.W. 536 (1917) (general improvements); Washington, State v. Yelle, I83 Wash. 380, 48 P. (2d) 573 (I935) (game conservation); West Virginia, Bates v. State Bridge Comm'n, I09 W. Va. I86, I53 S.E. 305 (1930); Wisconsin, Loomis v. Callahan, I96 Wis. 518, 220 N.W. $8 \mathrm{r} 6$ (r928) (dormitories); Wyoming, Arnold v. Bond, 47 Wyo. 236, 34 P. (2d) 28 (r934) (dormitories).

For cases in which municipal revenue bonds have been allowed, see note, 47 Harv. L. Rev. 688 (1934).

${ }^{8}$ See note 45 supra (dormitories in twelve cases, toll bridges in eight).

${ }^{49}$ Geffs and Hepburn, op. cit. supra note 34 .

so Stimson, The Exemption of Publicly Owned Property from Taxation, 8 U. of Cinn. L. Rev. 32, 46 (1934). Data therein were taken from Financial Statistics of Cities Having a Population of Over Thirty Thousand: I929, prepared by the United States Department of Commerce. 
of decisions, approving the use of revenue bond, when the state courts are called on to decide whether or not easy federal money can be accepted.

It is not at all clear that the courts have gone too far in such constructions of their respective constitutions. In evaluating their technique it is well to remember the orthodox canon of construction that limitations in state constitutions are to be construed narrowly since the state is a government of reserved powers.51 Further, because of the uncertain origins of these limitations, it is not clear that the framers intended anything more than that the state's general credit should not be used to finance public works. In any event it is hardly arguable that it is not better to go ahead with public works on this basis than to stop them altogether.

Yet it is unfortunate that additional safeguards could not be given the bondholders. The financing of the only improvement of comparable magnitude, the highways, is significant. They are either specifically exempted in the constitutions from the usual debt limits ${ }^{52}$ or are paid from special taxes. ${ }^{53}$ Over a long period of years it is entirely possible that some of these projects will meet with financial difficulties similar to those experienced by municipal plants, 54 with the loss by necessity falling entirely on the bondholders. In private financing there is a cushion supplied by the capital invested by stockholders, while, in ordinary public financing, the taxing power usually affords adequate protection. By contrast, the bondholders of the power projects supply all the capital invested except the P.W.A. grant of thirty per cent of the cost of plant construction. The only remedy given is the right to force rate increases if interest is not met, 55 but increased rates in the face of variable consumption do not assure increased revenues. The remedies of receivership and foreclosure would seem of questionable value. Further, these remedies have not been granted in the past ${ }^{36}$ and are not likely to be in the future since they would permit a state's creditors to take possession of its property, a result which is incompatible with state sovereignty. Particularly is this true if the bondholder happens to be the federal government. While reorganization is possible under the recently validated

sx Railroad Company v. County of Otoe, I6 Wall. (U.S.) 667 (1872); Powell v. Pennsylvania, 227 U.S. 678 (I888).

$s^{2}$ For example see: Calif. Const. art. $4, \S 36$; Kan. Const. art. Ir, §9; Me. Const. art. 34; Mich. Const. art. Io, § I0; Minn. Const. art. 9, § 5; Pa. Const. art. $9, \S 4$.

$53 \mathrm{~A}$ few of the cases in which this method was approved are: Williams v. Parnell, 185 Ark. Iro5, 5I S.W. (2d) 863 (r932); Johnson v. McDonald, 97 Colo. 324, 49 P. (2d) ror? (I935); Harrison v. Hardman, I69 Ga. 435, I5० S.E. 542 (I929); State ex. rel. Boynton v. State Highway Comm'n, I39 Kan. 39r, 32 P. (2d) 493 (r934).

54 The mortality rate for municipality owned power plants was high during the recent depression. It is estimated that out of 2300 plants existing in 1927 , only 1700 had survived until r932. Note 33 Col. L. Rev. 338 (1933).

${ }^{55} \mathrm{Geffs}$ and Hepburn, op. cit. supra note 34 .

${ }^{56}$ Except in New Hampshire, which allows receiverships. N.H. Laws 1935, c. 121 at 229. Held, constitutional. Conway v. New Hampshire Water Resources Board 5 U.S. Law Week 985 (N.H. Sup. Ct., April 19, r938). 
Municipal Bankruptcy Act ${ }^{57}$ such procedure is meaningless here since the bondholders have the only major financial interest..$^{8}$

These bonds may be sold to both private investors and the federal government. Until their soundness as investments is proved, however, it is probable that the national government will find it necessary to purchase the bulk of them. In fact, the government has provided a $\$ 500,000,000$ revolving fund for this purpose.59 The obvious result is that many of these projects are being entirely financed by federal money. In so far as the federal government has thus directly and indirectly financed the entire state program, a remarkable example of legal shadow-boxing is presented. Thus, like the direct federal program, many of the state developments are vulnerable to a change in Congressional sentiment.

Whether the bonds are owned privately or by the federal government, defaults would lead to an adverse-reaction toward state power activity in any form. A similar reaction to losses sustained by earlier state developments led to the present arbitrary constitutional debt limitations. The anomaly of a sovereign state imposing such limits upon itself emphasizes the need for proceeding on a sound basis to avoid a recurrence of a similar sentiment against worth-while state activity. Yet, the method used, revenue bond financing, is the one leaving creditors most vulnerable to the effects of general depressions. An unwholesome reaction can only be prevented by an integrated state program secured by the taxing power of the state. An adequate supply of private capital would be assured, thus guarding against changes in federal policy. South Dakota, by specific constitutional provision, ${ }^{60}$ has made the taxing power of the state available for electric power programs. While similar constitutional revision in other states may prove a tedious undertaking, it is necessary in order to assure the continued success of these essential projects. ${ }^{6 r}$

\section{PROSPECTIVE WAR LEGISLATION}

"A bill to prevent profiteering in time of war and to equalize the burdens of war and thus provide for the national defense, and promote peace" is the

${ }^{57} 50$ Stat. 653 (1937), I I U.S.C.A. § 40r (1937), upheld in Bekins v. Lindsey-Strathmore Irrigation Dist., 5 U.S. Law Week too4 (U.S. Sup. Ct., April 26, x938).

${ }^{58}$ General creditors would also sustain a loss, but their interests will probably be minute, compared to that of the bondholders.

59 Geffs and Hepburn, op. cil. supra note 34 .

${ }^{60}$ S.D. Const. art. $13, \S 12$, discussed in In re Opinion of the Judges, 43 S.D. 635,177 N.W. 812 (1920).

A similar attempt was made to amend the Wisconsin constitution. Wis. L. r93x, p. 923. A parliamentary maneuver in 1933 amended the proposal, requiring an additional legislative vote. Wis. L. I933, p. I28 r. Unfortunately, the amended proposal was defeated in 1935 .

or Existing projects could be encompassed by these revisions without losing present work relief benefits. 